\title{
The Semantic Frames and Quantitative Characteristics of Chinese Event Noun
}

\author{
Zhong Wu* \\ Jianghan University, School of Foreign Languages, 430056 Wuhan, China \\ *Corresponding author. Email: zhongwu2000@163.com
}

\begin{abstract}
Event noun is an atypical noun, representing event instead of object. Based on the theory of frames semantics, this article aims at studying the semantic frames and quantitative characteristics of event nouns and finds that nouns in the same event domain have the same semantic frame. Generally speaking, the core frame elements of greater prominence are more likely to form event nouns. Besides, the quantitative characteristic of event noun is closely related to its semantic frame, maintaining the features of the spatiality of common noun, so that it can co-occur with noun classifiers. Furthermore, event noun boasts the temporal and bounded characteristics of social phenomena, for which it can co-occur with time classifiers and verb classifiers as well.
\end{abstract}

Keywords: Event noun, Semantic frame, Quantitative characteristics.

\section{INTRODUCTION}

The universe is composed of objects and events. Objects, associating with space, are real entities, while events, associating with time, are relationships and dynamic changes of various objects. The concept of "event" is widely used in language and can manifest as sentences or even as event nouns, transferring information in communication. Therefore, event noun emerges as atypical noun as it has the temporal semantic characteristics of verb as well as the spatial characteristics of noun. This research will explore the semantic frames and quantitative characteristics of Chinese event nouns.

\section{RELATED RESEARCHES}

Event noun is the manifestation of the "process" of actions, behaviours, and events [1]. It has dynamic, procedural, and temporal characteristics, which is different from common noun semantically.

Zeno Vendler finds some English nouns such as "fire" and "blizzard" are different from those nouns like "table", "crystal" and "cow" [2]. Denoting an event instead of an object and emerging as temporal entity, they can happen, start, stop or be observed. Yu, from the perspective of meaning, categorized event nouns into two groups, i.e. natural phenomena such as "thundershowers", "droughts" and "storms" and certain human activities like "preliminary" and "parade" [3]. Similarly, Lu divided these nouns into two categories: the "complex events" mainly representing social phenomena and "non- autonomous events" referring to natural phenomena [1].

This research attempts to study event nouns with the frames semantics theory. According to the theory, people understand word meaning with the help of its semantic frame.

The concept of "frames" was introduced into linguistic by Charles Fillmore who believes that "frames" is a conceptual system. For those who aspire to understand any concepts in the system, he must figure out the overall structure. According to frames semantics, the comprehending and defining of the word meaning rely on the frame itself. The interpretation of any concept in the frame must refer to structure, belief and practical experience of daily life.

Domestically, the study on event nouns, in the initial stage so far, has focused on its definition and the description of its syntactic functions, and has done little to the semantic characteristics and cognitive mechanisms. 


\section{THE SEMANTIC FRAMES OF CHINESE EVENT NOUNS}

Fillmore believes that "frame" does not exist in the real world, but emerges as a prototype that can explain the complicated relationships between word and the real world and is influenced by the background of social activities [4]. It is necessary to provide a conceptual structure of background for those who wants to understand the meaning of a word. The structure is what we call "semantic frame". The frame connects empirical knowledge with language structure, facilitating the description and understanding of the word meaning. In other word, with the semantic frame and the way in which it describes, it's more convenient to study the relationship between words in the same frame.

Frame semantic analysis is dynamic in connecting scenes. That is to say, meaning is related to scenes, but scenes are not identical with meaning, as meaning cannot be explained without language users. The participants and external factors are considered as frame elements, which refer to myriad roles constituting the semantic structure in a certain semantic frame, such as buyer, seller, commodity, price and time in the domain of transaction.

The prototype of Chinese event noun for competition is “Bǐsàì"(比赛 'match'), which can be used as a verb to mean comparing skills and techniques in sports, production or other activities. Also, it serves as a noun, referring to "competitive activities" (The Contemporary Chinese Normative Dictionary). Generally speaking, elements of the match domain include factors like agency, event/affair, tool, process, result, scope, location, time, quantity and restriction. Most of the event nouns are attribute-center structure, consisting of a modifying morpheme and a central morpheme "sài” (赛 'match').

With the retrieving function of BCC corpus, a query formulation, "v/n/a/d + sàı", will be used as keywords to retrieve the corpus [5]. After deleting the downloaded interference indexes, it is found that the modifying morphemes of event nouns can be nominal or non-nominal.

E.g.:

Noun+sài:

zúqiú sài 足球赛 'football match';

zhàng'ài sài 障碍赛 'obstacle course’;

tuántǐ sài 团体赛 'team match';

jīnpái sài 金牌赛 'gold medal match’

Verb+sài:

gàobié sài 告别赛 'farewell match'; rèshēn sài 热身赛 'warm-up match’

Adjective+sài:

císhàn sài 慈善赛 'charity match'; zhèngshì sài 正式赛 'official match'
The modifying morpheme inside a event noun can even be a phrase.

E.g.:

Phrase+sài:

jìhò sài 季后赛 'playoffs';

jiāshi sài 加时赛 'overtime’

Besides the morphological construction of event nouns, the frame elements in the match domain can also serve as modifiers in event nouns.

E.g.:

Agent + sài:

xīnxiù sài 新秀赛'rookie game';

quán míngxīng sài 全明星赛 'all-star game’;

gèrén sài 个人赛 'individual game'

Events / affairs + sài:

róudào sài 柔道赛 'Judo competitions';

mónì sài 模拟赛 'simulation competitions';

dānxiàng sài 单项赛 'individual events'

Tools + sài

lóngzhōu sài 龙舟赛 'Dragon Boat Race'; zìxingchē sài 自行车赛 'Bicycle Race'; wăngqiú sài 网球赛 'Tennis Race'

Process + sài:

xiăozǔ sài 小组赛 'group stage';

fùjiā sài 附加赛 'play-offs';

bàn juésài 半决赛 'semi-finals'

Results + sài:

guànjūnsài 冠军赛 'championship';

jǐnbiāosài 锦标赛 'tournament'

Range + sài:

quánguó sài 全国赛 'National Competition'

Location + sài:

xiàoyuán sài 校园赛 ‘campus competition';

shìnèi sài 室内赛 'indoor competition'

Time + sài:

jì hòu sài 季后赛 'playoffs'

The value and role of different frame elements are not the same in a frame. According to the criteria of significance, frame elements fall into two types: core elements and non-core elements. The core element refers to the foreground component that is highlighted in a frame. As the most critical component, it shows the feature of a frame. And different frames involve different types and quantities of core elements. Non-core element, referring to the background element, does not show the characteristics of a frame and is not highlighted. Besides, non-core elements appear in nearly all frames and are often called peripheral elements. The typical examples of them are time and location [6]. 
Among the above-mentioned event nouns, agents, things/affairs and tools are core elements, acting as the prominent foreground, while process, result, scope, location and time are peripheral elements of background. Furthermore, in terms of statistic data, the number of event nouns composed of certain frame elements, such as agents, things/affairs and tools, is far greater than that of peripheral elements. In other words, core elements are the focus of cognition, while the non-core one, serving as the background, is not.

Thus, in the match domain, basketball, chess, judo and cycle are the focus of cognition and also the most distinguishing elements. And they work as the core elements in the semantic frame naturally, which appear more frequently than non-core ones.

To sum up, each frame formulation has a specific frame semantic construction. As the background of the semantic frame and a lemma that can activate the match scene, the head morpheme "sai" can co-occur with all types of frame elements. Some highlighted core elements such as agents, things/affairs and tools, tend to appear more frequently and are more likely to form event nouns.

\section{THE QUANTITATIVE CHARACTERISTICS AND COGNITIVE INTERPRETATION OF CHINESE EVENT NOUNS}

One prominent characteristic of Chinese is the collocation of classifiers and nouns, which is different from Indo-European languages. Classifiers are often used as a syntactic criterion for semantic classification of nouns and are classified into noun classifier, verb classifier and time classifier. Noun classifiers are modifiers of nouns which indicate the number of objects while verb classifiers are usually used after verbs to indicate the times of actions, and time classifiers represent the quantity of time. Han Lei, by studying the frequency of combination of the typical event nouns and classifiers in the CCL corpus, found that the priority of collocation is shown as follow: verb classifier > time classifier $>$ noun classifier. She believes that the [+temporal] semantic characteristic of classifiers and event nouns are reasons for such phenomena [7].

Similarly, it is found that event nouns of matches can co-occur with verb classifiers, time classifiers, and noun classifiers in the $\mathrm{BCC}$ corpus.

E.g.1 赛。

英国著名赛车杂志评选出了全世界八种最佳房车

Yīngguó zhùmíng sàichē zázhìpingxu ăn zhōng píngxuăn chūle quán shìiè bāahơ̌ng zuì jiā fángchēsài.

The well-known British racing magazine has selected eight best touring car races in the world.
E.g.2

中国队计划在广州进行两场热身赛。

Zhōngguóduì jìhuà zài guăngzhōu jinxing

liăngchăng rèshēnsài.

The Chinese team plans to play two warm-up matches in Guangzhou.

E.g.3

(双方) 只好再踢 20 分钟加时赛。

(Shuāngfāng) zh ǐhăo zài tī 20 fēnzhōng jiāshísài.

(Both sides) have to play another 20 minutes of overtime.

Language is a manifestation of people's thinking mode in understanding objective events. With human's cognitive ability, the construction of verbal events reflects objective events through syntactic functions, indirectly but actively.

Among above examples, E.g. 1 illustrates a noun classifier “ $z h$ ǒng”( 种 'type') modifying event noun “fángchēsài”" (房车赛“touring car race'); E.g. 2 shows that a verb modifier "chăng"(场“used as an indefinite article in entertainment or sports' ) modifying event noun “rèshēnsài” (热身赛 'warm-up match'); and a time classifier “fênzhōng”( 分 钟 'minute') modifies “jiāshísài” (加时赛‘overtime’) in E.g. 3.

Language is a subjective manifestation of the objective world, and the quantitative characteristics of words are also closely related to their semantic characteristics. Firstly, the semantic characteristics of the noun's spatiality still remains with the event noun even it is an atypical one. As such, it can co-occur with noun classifier “ $z h o$ ong”(种“type') syntactically in E.g. 1, indicating the types of objects or events.

Secondly, event nouns of match are also manifestation of social phenomena in language. With the characteristics of temporality, they can co-occur with time classifiers such as "fênzhōng" in E.g. 2. It is very common that matches usually last for hours or days, and results of competitions are often recorded with minute or second in the real word. After retrieving the BCC corpus, it is found that event nouns of match are often associated with time classifiers which indicating minute or seconds, but seldom connects with those representing week, month or year.

E.g.4

乒乓球比赛结束了为期两天的小组赛争夺。

Pīngpāng qiú bisài jiéshùle wéiqi li ăngtiān de xiăozŭsài zhēngduó.

A two-day group competition of table tennis ended.

\section{E.g.5}

经过两个半小时的加赛才分出高下。

Jìngguò li ănggèbànxi ăoshí de ïiāsài cái fènchū gāoxià. 
After two and a half hours of playoffs, the ultimate winner has been decided.

E.g.6

卫冕冠军以 1 小时 28 分 12 秒 058 的成绩夺得了 分站赛冠军。

Wèimiăn guànjūn y 1 xiăoshí 28 fēn 12 miăo 058 de chéngjī duó déliăo fênzhànsài guànjūn.

The defending champion won the race championship in 1 hour 28 minutes 12 seconds 058.

Finally, event noun also has the characteristic of boundedness. Each competition or match is a complete event, with the starting point and the ending point. The boundedness of common nouns refer to the boundedness in space, while the boundedness of event nouns refer to the boundedness in time, which is also the cognitive boundary of a specific event in the real world.

Therefore, event nouns, reflecting scenes of match, can also syntactically co-occur with verb classifiers such

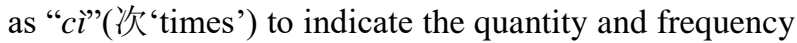
of those events.

After searching the corpus with the combination of event nouns and classifiers, it is found that the order of priority is similar to the findings of Han [7]: verb classifier > temporal classifier > noun classifier. On the one hand, the [+temporal] semantic characteristics of the classifier account for the above priority; on the other hand, it illustrates the fact that the cognitive boundary, frequency and amplitude of matches are the measuring focus of the semantic frame.

A safe conclusion can be reached that the quantitative characteristics of event nouns also depends on their semantic frames. With the semantic characteristics of space, time and boundedness, event nouns of match can co-occur with noun classifiers, time classifiers and verb classifiers, showing their peculiar quantitative characteristics.

\section{CONCLUSIONS}

Event nouns are nouns indicating actions and event processes, which are different from common nouns. A frame is a prototype that explains the connection between words and real scenes. Guided by the Frames Semantics theory, this article, taking event nouns of match as examples, discusses the semantic frames and quantitative characteristics of these special nouns. Researchers found that the lemma "sài" can activate the match scene and form event nouns with various frame elements, among which, "agents, things/affairs and tools" are core elements and also the most prominent elements. They play a major role in constituting event nouns of this type. Furthermore, the semantic frames of event nouns also affect their quantitative characteristics. Event nouns of match are manifestation of social phenomena in language, so they possess semantic characteristics of space, time and boundedness. They can co-occur with noun classifiers, time classifiers, and verb classifiers, demonstrating peculiar quantitative characteristics different from those of common nouns.

\section{ACKNOWLEDGMENTS}

This research was financially supported by Hubei Provincial Department of Education (18G039, A Cognitive Research on Event Nouns in Modern Chinese).

\section{REFERENCES}

[1] Lu Bingfu. The semantic characteristics of "event nouns" in Chinese and English. Contemporary Linguistics, 2012 (1):1-11.

[2] Zeno Vendler: Linguistics in Philosophy (English-Chinese version), translated by Chen Jiaying. Beijing: China Publishing House, 2002.

[3] Yu Shiwen et al. Detailed Explanation of Modern Chinese Grammar Information Dictionary (Second Edition). Beijing: Tsinghua University Press, 2002

[4] Fillmore, Charles. Frames semantics. In The Linguistic Society of Korea (ed.), Linguistics in the Morning Calm, 111-137, Seoul: Hanshin.

[5] Xun Endong, Rao Gaoqi, Xiao Xiaoyue, Zang Jiaojiao. The development of BCC corpus under the background of big data. Corpus Linguistics, 2016 (1):93-109

[6] Ma Honghai. Research on Chinese Frames Semantics. Beijing: China Social Sciences Press, 2010.

[7] Han Lei.The Selection of Event Nouns and Classifiers--A Casestudy of "Yu". Journal of East China Normal University (Philosophy and Social Sciences), 2007(3):64-68. 